\title{
LYMPHOPARIETAL INDEX IN ESOPHAGEAL CANCER IS STRONGER THAN TNM STAGING IN LONG-TERM SURVIVAL PROGNOSIS IN A LATIN-AMERICAN COUNTRY
}

\author{
Índice linfoparietal no câncer esofágico é mais forte do que TNM no prognóstico de sobrevivência em longo \\ prazo em um país latinoamericano
}

\section{Manuel FIGUEROA-GIRALT ${ }^{1 \oplus}$, Catalina VALENZUELA ${ }^{1 \oplus}$, Andrés TORREALBA ${ }^{1 \oplus}$, Attila CSENDES $^{1 \oplus}{ }^{\oplus}$, Italo BRAGHETTO $^{1 \oplus}$, Enrique LANZARINI ${ }^{1 \oplus}$, Maher MUSLEH ${ }^{1 \oplus}$, Owen KORN $^{1 \oplus}$, Hector VALLADARES ${ }^{1 \oplus}$, Solange CORTÉS ${ }^{1 \odot}$}

\begin{abstract}
Background: The identification of prognostic factors of esophageal cancer has allowed to predict the evolution of patients. Aim: Assess different prognostic factors of long-term survival of esophageal cancer and evaluate a new prognostic factor of long-term survival called lymphoparietal index $(\mathrm{N}+/ \mathrm{T})$. Method: Prospective study of the Universidad de Chile Clinical Hospital, between January 2004 and December 2013. Included all esophageal cancer surgeries with curative intent and cervical anastomosis. Exclusion criteria included: stage 4 cancers, R1 resections, palliative procedures and emergency surgeries. Results: Fifty-eight patients were included, $62.1 \%$ were men, the average age was 63.3 years. A total of $48.3 \%$ were squamous, $88 \%$ were advanced cancers, the average lymph node harvest was 17.1 . Post-operative surgical morbidity was $75 \%$, with a $17.2 \%$ of reoperations and $3.4 \%$ of mortality. The average overall survival was 41.3 months, the 3-year survival was $31 \%$. Multivariate analysis of the prognostic factors showed that significant variables were anterior mediastinal ascent $(p=0.01, O R: 6.7[1.43-31.6])$, anastomotic fistula $(p=0.03, O R: 0.21$ $[0.05-0.87])$, $N$ classification ( $p=0.02$, OR: 3.8 [1.16-12.73]), TNM stage ( $p=0.04$, OR: 2.8 [1.01-9.26]), and lymphoparietal index ( $p=0.04$, RR: 3.9 [1.01-15.17]. The ROC curves of lymphoparietal index, $\mathrm{N}$ classification and TNM stage have areas under the curve of $0.71,0.63$ and 0.64 respectively, with significant statistical difference $(p=0.01)$. Conclusion: The independent prognostic factors of long-term survival in esophageal cancer are anterior mediastinal ascent, anastomotic fistula, $\mathrm{N}$ classification, TNM stage and lymphoparietal index. In esophageal cancer the new lymphoparietal index is stronger than TNM stage in long-term survival prognosis.

HEADINGS - Esophageal neoplasms. Survival. Prognosis.
\end{abstract}

\begin{tabular}{l}
\hline Central message \\
\hline The main prognostic factors of esophageal cancer \\
long-term survival are anterior mediastinal ascent, \\
anastomotic fistula, $\mathrm{N}$ classification, TNM stage and \\
lymphoparietal index. The new lymphoparietal index \\
is stronger than TNM stage in long-term survival \\
prognosis.
\end{tabular}

\section{Perspective}

Knowing the prognostic factors allows to make an accurate informed consent, and determine the best treatment option for a specific patient. The new lymphoparietal index is an extra tool that should be consider.

RESUMO - Racional: A identificação de fatores prognósticos do câncer de esôfago permitiu prever a evolução dos pacientes. Objetivo: Avaliar diferentes fatores prognósticos da sobrevida em longo prazo do câncer de esôfago e avaliar um novo fator prognóstico da sobrevida em longo prazo chamado índice linfoparietal $(\mathrm{N}+/ \mathrm{T})$. Método: Estudo prospectivo do Hospital Clínico da Universidade do Chile, entre janeiro de 2004 e dezembro de 2013. Incluiu todas as operações de câncer de esôfago com intenção curativa e anastomose cervical. Os critérios de exclusão incluíram: câncer em estágio 4, ressecções R1, procedimentos paliativos e operações de emergência. Resultados: Cinquenta e oito pacientes foram incluídos, 62,1\% eram homens, a idade média foi de 63,3 anos. Um total de 48,3\% eram escamosos, $88 \%$ eram cânceres avançados, a colheita média de linfonodos foi de 17,1. A morbidade cirúrgica pós-operatória foi de $75 \%$, com $17,2 \%$ de reoperações e 3,4\% de mortalidade. A sobrevida global média foi de 41,3 meses, a sobrevida em três anos foi de $31 \%$. A análise multivariada dos fatores prognósticos mostrou que variáveis significativas foram elevação pelo mediastinal anterior $(p=0,01,0 R: 6,7$ $[1,43-31,6])$, fístula anastomótica ( $p=0,03$, OR: 0,21 [0,05-0,87]), classificação $N(p=0,02$, OR: 3,8 $[1,16-12,73])$, estágio TNM ( $p=0,04$, OR: $2,8[1,01-9,26])$ e índice linfoparietal $(p=0,04, R R: 3,9$ $[1,01-15,17]$. As curvas ROC do índice linfoparietal, classificação N e estádio TNM apresentam áreas abaixo da curva de 0,71, 0,63 e 0,64, respectivamente, com diferença estatística significativa $(p=0,01)$. Conclusão: Os fatores prognósticos independentes de sobrevida em longo prazo no câncer de esôfago são a elevação mediastinal anterior, fístula anastomótica, classificação $\mathrm{N}$ estágio TNM e índice linfoparietal. No câncer de esôfago, o novo índice linfoparietal é mais forte que o estágio TNM no prognóstico de sobrevida em longo prazo.

DESCRITORES: Neoplasias esofágicas. Sobrevida. Pronostico.

How to cite this article: Figueroa-Giralt M, Valenzuela C, Torrealba A, Csendes A, Braghetto I, Lanzarini E, Musleh M, Korn O, Valladares H, Cortés S. Lymphoparietal index in esophageal cancer is stronger than TNM staging in long-term survival prognosis in a latin-american country. ABCD Arq Bras Cir Dig. 2020;33(3):e1547. DOI: /10.1590/0102$672020200003 e 1547$

Correspondence:

Manuel Figueroa-Giralt

E-mail: manuelfigueroa.gi@gmail.com
Financial source: none

Conflict of interest: none

Received for publication: 31/01/2020

Accepted for publication: 02/05/2020 
INTRODUCTION

T he identification of some prognostic factors in oncologic disease has allowed to predict patient's evolution and guided therapeutic decision-making process to improve long-term survival ${ }^{18,26}$. However, in Chilean reality there are insufficient studies that analyze multiple prognostic factors of long-term survival in esophageal cancer r $^{1-7,29-32}$.

The main objective of this study was to assess different prognostic factors of long-term survival in esophageal cancer. Secondary objectives were: a) analyze post-operative evolution; b) determine global overall survival greater than three years (OS3); and c) assess the value of a new prognostic factor of long-term survival called lymphoparietal index $(\mathrm{N}+/ \mathrm{T})$, previously validated in gastric cancer ${ }^{12,13}$.

METHOD

This study was a prospective analysis of the oncological database of a Chilean University (Clinical Hospital of the University of Chile) between January 2004 and December 2013.

\section{Ethical standards}

This article does not contain any experimental studies with human or animal subjects performed by any of the authors.

\section{Patients}

All patients with esophageal cancer in adult population, surgically treated with a curative intent, were identified, and only total esophagectomies with gastric tube ascent and cervical anastomosis where included. All patients were presented to the hospital oncology committee and treated with neoadjuvant or adjuvant therapy according to tumor stage. Exclusion criteria included were: proximal tumors, Siewert 3, stage 4 cancers, $\mathrm{R} 1$ resections, palliative procedures and emergency surgeries

\section{Surgical technique.}

The surgeries were performed by surgeons with vast experience in oncological esophagectomies. All patients were subjected to minimally invasive thoraco-abdominal esophagectomy and cervical anastomosis. The thoracic time was done in the first years transhiatal and then by videothoracoscopy in left lateral decubitus. The gastric tube was made in the first years open and then laparoscopic with linear staplers from the distal aspect of the lesser curvature to the gastric fundus, $5 \mathrm{~cm}$ to the grater curve of the stomach preserving the gastro-omental arcade. The left gastro-omental vessels, right and left gastric vessels were cut. The gastric tube was pulled upwards to the cervical compartment through anterior or posterior mediastinal way according to surgeon preference. The lymphadenectomy was standard in two fields. All patients had an intra-operative contemporary biopsy.

\section{Definitions}

The definitions used were: a )TNM classification was standarized using the AJCC 7 th edition $\left.{ }^{5} ; b\right)$ the lymphoparietal index $(\mathrm{N}+/ \mathrm{T})$ calculates the quotient between the number of lymph nodes that are positive for adenocarcinoma metastasis and the $T$ classification of the patient ${ }^{12,13}$, examples: $1 /$ $\mathrm{T} 1 \mathrm{a}=1 / 1=1,6 / \mathrm{T} 3=6 / 3=2,24 / \mathrm{T} 4 \mathrm{~b}=24 / 4=6$ ) and the ratio results were divided into $\mathrm{N}+/ \mathrm{T}_{\mathrm{A}}: 0-0.5$ and $\mathrm{N}+/ \mathrm{T}_{\mathrm{B}}:>0.5 ; \mathrm{c}$ ) surgical mortality was defined as occurring from the moment of surgery up to postoperative day 90; d) global survival was defined as of when the patient was discharged from the hospital, eliminating surgical mortality; e) long term survival was defined as survival greater than three years postoperative; f) zero time for determining prognostic association was the esophagectomy.

\section{Follow up}

The present study had $100 \%$ follow up. The database was completed in a prospective manner: the survival update was carried out annually using the database of our hospital and the Chilean Civil Registry.

\section{Statistical analysis}

The prognostics factors evaluated were demographic, clinical, surgical, anatomopathological and prognostic indexes, 31 variables in total. The distribution of variables was determined by the Shapiro-Wilk test. In accordance with this test, the continuous variables with parametric distribution (ordinal) were expressed on average and standard deviation (SD), while for the non-parametric distribution (nominal) the median and inter-quartile $\left(\mathrm{IC}_{25 \%-75 \%}\right)$ ranges were used. The categorical variables were described in percentages. The Fisher, $x^{2}, t$ Student and Wilcoxon Rank-Sum tests were used based on the characteristics and distribution of the variables. For the analytical statistical analysis, the Stata ${ }^{\mathrm{R}} 14$ program was used and $p<0.05$ was considered statistically significant. Univariate and multivariate analyses were performed calculating the odds ratio (OR) with a $95 \%$ confidence interval $(\mathrm{Cl})$. The Kaplan-Meier method was used to calculate the survival curves, and the ROC curves to assess the prognosis accuracy of the variables ${ }^{14}$

\section{RESULTS}

A total of 95 patients had surgery for esophageal cancer and 55 were included in the study according to exclusion criteria. The mean age was 63.3 years ( \pm 10.4 DS) of which $62.1 \%$ were male, $74.1 \%$ of patients presented comorbidities with tabacco, high blood pressure and pathological gastroesophageal reflux disease being the most common with $48.3 \%, 44.83 \%$ and $43.1 \%$ respectively. According to the ASA classification, $52.7 \%$ were ASA I, $47.3 \%$ were ASA II and III.

With regards to the clinical manner, $81.8 \%$ presented epigastric pain, $50.9 \%$ weight loss and $21.8 \%$ pain. Anemia (hematocrit $<35 \%$ ) was observed in $16.4 \%$, while protein malnutrition (albumin $<3.5 \mathrm{mg} / \mathrm{dl}$ ) was present in $7.3 \%$.

In reference to the surgical technique, $61.8 \%$ of patients had anterior mediastinal pull-up of gastric tube. The median global lymph node harvest was 17.1 lymph nodes $\left(\mathrm{IC}_{25-75 \%}\right.$ : 11-35).

The mean hospital stay was 24 days ( $+18 D S)$. Postoperative morbidity corresponded to $75 \%$, reoperations to $17.2 \%$, while surgical mortality was $3.4 \%$ (Table 1 ).

The histopathological study revealed that $65.5 \%$ of the tumors were localized in the distal esophagus, $52.7 \%$ of the sample was adenocarcinoma, $88 \%$ of the tumor were advanced and $72.7 \%$ of all had moderate to poor degree of differentiation. The TNM stage is specified in Table 2.

The mean global survival was 41.3 months (interval between 1 and 178 months, DS +/-47.2). The rate of patients with an OS3 was $32.7 \%$. The survival curve is detailed in Figure 1.

In the lymphoparietal index Kaplan-Meier analysis, a statistically significant difference was seen in the global long-term survival between subgroups $\left(\mathrm{N}+/ \mathrm{T}_{\mathrm{A}}\right.$ and $\left.\mathrm{N}+/ \mathrm{T}_{\mathrm{B}}\right)$ $\mathrm{p}<0.009$, Figure 2).

The multivariate analysis of the prognostic factors is represented in Table 2, the significant variables are: anterior mediastinal pull-up, anastomotic fistula, $\mathrm{N}$ classification, TNM stage, and lymphoparietal index (Table 2).

The ROC curve of lymphoparietal index, $\mathrm{N}$ classification and TNM stage showed the respectively areas below the curves $0.71,0.63$ and $0.64(p=0.01$, Figure 3$)$ 
LYMPHOPARIETAL INDEX IN ESOPHAGEAL CANCER IS STRONGER THAN TNM STAGING IN LONG-TERM SURVIVAL PROGNOSIS IN A LATIN-AMERICAN

TABLE 1 - Univariable analysis of demographic, clinical, surgical and oncologic variables of long-term survival in esophageal cancer.

\begin{tabular}{|c|c|c|c|c|c|c|c|}
\hline \multirow{2}{*}{ Variável } & \multicolumn{2}{|c|}{$\mathrm{OS}<3$} & \multicolumn{2}{|c|}{$O S>3$} & \multicolumn{3}{|c|}{ Univariable analysis } \\
\hline & $n=37$ & $\%$ & $n=18$ & $\%$ & $\mathrm{p}$ & OR & Cl 95\% \\
\hline \multicolumn{8}{|l|}{ Gender } \\
\hline Male & 26 & $70.3 \%$ & 8 & $44.4 \%$ & \multirow{2}{*}{0.08} & & \\
\hline Female & 11 & $29.7 \%$ & 10 & $55.6 \%$ & & & \\
\hline Age & 63.5 & & 61.7 & & 0.17 & & \\
\hline \multicolumn{8}{|l|}{ ASA } \\
\hline 1 & 22 & $59.5 \%$ & 7 & $38.9 \%$ & & & \\
\hline II-III & 15 & $40.5 \%$ & 11 & $0.0 \%$ & 0.07 & & \\
\hline Comorbidities & & & & & & & \\
\hline Hypertension & 19 & $51.4 \%$ & 5 & $27.8 \%$ & 0.14 & & \\
\hline Diabetes & 7 & $18.9 \%$ & 1 & $5.6 \%$ & 0.25 & & \\
\hline COPD & 4 & $10.8 \%$ & 0 & $0.0 \%$ & 0.29 & & \\
\hline Tabacco & 19 & $51.4 \%$ & 8 & $44.4 \%$ & 0.7 & & \\
\hline BMI (kg/mt2) & & & & & & & \\
\hline$<25$ & 15 & $40.5 \%$ & 7 & $38.9 \%$ & & & \\
\hline$>25$ & 22 & $59.5 \%$ & 11 & $61.1 \%$ & 0.99 & & \\
\hline Esophageal dis & & & & & & & \\
\hline GERD & 13 & $35.1 \%$ & 11 & $61.1 \%$ & 0.08 & & \\
\hline BARRETT & 8 & $21.6 \%$ & 7 & $38.9 \%$ & 0.21 & & \\
\hline $\mathrm{HH}$ & 6 & $16.2 \%$ & 1 & $5.6 \%$ & 0.41 & & \\
\hline Symptoms and & & & & & & & \\
\hline Disphagia & 30 & $81.1 \%$ & 15 & $83.3 \%$ & $>0.99$ & & \\
\hline Weight loss & 22 & $59.5 \%$ & 6 & $33.3 \%$ & 0.08 & & \\
\hline Pain & 9 & $24.3 \%$ & 3 & $16.7 \%$ & 0.72 & & \\
\hline Laboratory & & & & & & & \\
\hline HTO <35\% & 8 & $21.6 \%$ & 1 & $5.6 \%$ & 0.24 & & \\
\hline $\mathrm{Alb}<3.5 \mathrm{mg} / \mathrm{dl}$ & 2 & $5.4 \%$ & 2 & $11.1 \%$ & 0.59 & & \\
\hline Localization & & & & & & & \\
\hline Middle & 11 & $29.7 \%$ & 8 & $44.4 \%$ & & & \\
\hline Distal & 26 & $70.3 \%$ & 10 & $55.6 \%$ & 0.37 & & \\
\hline Pull-up & & & & & & & \\
\hline AP & 20 & $54.1 \%$ & 14 & $77.8 \%$ & & & $0.002-$ \\
\hline PP & 17 & $45.9 \%$ & 4 & $22.2 \%$ & 0.04 & 2.02 & 0.48 \\
\hline Esophageal fist & & & & & & & \\
\hline Yes & 29 & $78.4 \%$ & 8 & $44.4 \%$ & & & \\
\hline No & 8 & $21.6 \%$ & 10 & $55.6 \%$ & 0.016 & 1.76 & $1.11-3.25$ \\
\hline Mediastinal abs & & & & & & & \\
\hline Yes & 7 & $18.9 \%$ & 3 & $16.7 \%$ & & & \\
\hline No & 30 & $81.1 \%$ & 15 & $83.3 \%$ & $>0.99$ & & \\
\hline Pleural effusion & & & & & & & \\
\hline Yes & 2 & $5.4 \%$ & 2 & $11.1 \%$ & & & \\
\hline No & 35 & $94.6 \%$ & 16 & $88.9 \%$ & 0.59 & & \\
\hline Pneumonia & & & & & & & \\
\hline Yes & 8 & $21.6 \%$ & 1 & $5.6 \%$ & & & \\
\hline No & 29 & $78.4 \%$ & 17 & $94.4 \%$ & 0.24 & & \\
\hline Arrythmia & & & & & & & \\
\hline Yes & 5 & $13.5 \%$ & 2 & $11.1 \%$ & & & \\
\hline No & 32 & $86.5 \%$ & 15 & $83.3 \%$ & $>0.99$ & & \\
\hline Histology & & & & & & & \\
\hline EC & 18 & $48.6 \%$ & 8 & $44.4 \%$ & & & \\
\hline ADN & 19 & $51.4 \%$ & 10 & $50.0 \%$ & $>0.99$ & & \\
\hline Tumor grade & & & & & & & \\
\hline Well & 9 & $24.3 \%$ & 6 & $33.3 \%$ & & & \\
\hline Moderate & 18 & $48.6 \%$ & 12 & $66.7 \%$ & 0.02 & 0.6 & $0.35-0.89$ \\
\hline Bad & 10 & $27.0 \%$ & 0 & $0.0 \%$ & & & \\
\hline TNM & & & & & & & \\
\hline Tis & 0 & $0.0 \%$ & 1 & $5.6 \%$ & & & \\
\hline T1a & 0 & $0.0 \%$ & 1 & $5.6 \%$ & & & \\
\hline $\mathrm{T} 1 \mathrm{~b}$ & 2 & $5.4 \%$ & 2 & $11.1 \%$ & 0.06 & & \\
\hline $\mathrm{T} 2$ & 9 & $24.3 \%$ & 5 & $27.8 \%$ & & & \\
\hline T3 & 26 & $70.3 \%$ & 7 & $38.9 \%$ & & & \\
\hline NO & 8 & $21.6 \%$ & 11 & $61.1 \%$ & & & \\
\hline N1 & 11 & $29.7 \%$ & 4 & $22.2 \%$ & & & \\
\hline N2 & 10 & $27.0 \%$ & 4 & $22.2 \%$ & 0.01 & 0.54 & $0.29-0.86$ \\
\hline N3 & 7 & $18.9 \%$ & 0 & $0.0 \%$ & & & \\
\hline Stage & & & & & & & \\
\hline 0 & 0 & $0.0 \%$ & 1 & $5.6 \%$ & & & \\
\hline IB & 0 & $0.0 \%$ & 2 & $11.1 \%$ & & & \\
\hline IIA & 4 & $10.8 \%$ & 7 & $38.9 \%$ & & & \\
\hline IIB & 5 & $13.5 \%$ & 1 & $5.6 \%$ & 0.023 & 0.00 & $0.00-0.87$ \\
\hline IIIA & 4 & $10.8 \%$ & 1 & $5.6 \%$ & & & \\
\hline IIIB & 9 & $24.3 \%$ & 6 & $33.3 \%$ & & & \\
\hline IVA & 7 & $18.9 \%$ & 0 & $0.0 \%$ & & & \\
\hline Lymphora & & & & & & & \\
\hline $\mathrm{A}(0-0.5)$ & 13 & $35.1 \%$ & 13 & $72.2 \%$ & & & \\
\hline $\mathrm{B}(>0.5)$ & 24 & $64.9 \%$ & 5 & $27.8 \%$ & 0.02 & 0.6 & 0.37 \\
\hline
\end{tabular}

TABLE 2-Multivariable analysis oflong-term survival in esophageal cancer

\begin{tabular}{|l|c|c|c|}
\hline \multirow{2}{*}{\multicolumn{1}{c}{ Variable }} & \multicolumn{3}{c|}{ Multivariable analysis } \\
\cline { 2 - 4 } \multicolumn{1}{c|}{$\mathrm{p}$} & $\mathrm{OR}$ & $\mathrm{Cl} 95 \%$ \\
\hline Gender & 0.03 & 3.9 & $1.10-14.14$ \\
\hline Pull-up & 0.01 & 6.7 & $1.43-31.60$ \\
\hline Fistula & 0.03 & 0.2 & $0.05-0.87$ \\
\hline $\mathrm{N}$ & 0.02 & 3.8 & $1.16-12.73$ \\
\hline TNM stage & 0.04 & 2.8 & $1.01-9.26$ \\
\hline Lymphoparietal index & 0.04 & 3.9 & $1.01-15.17$ \\
\hline
\end{tabular}

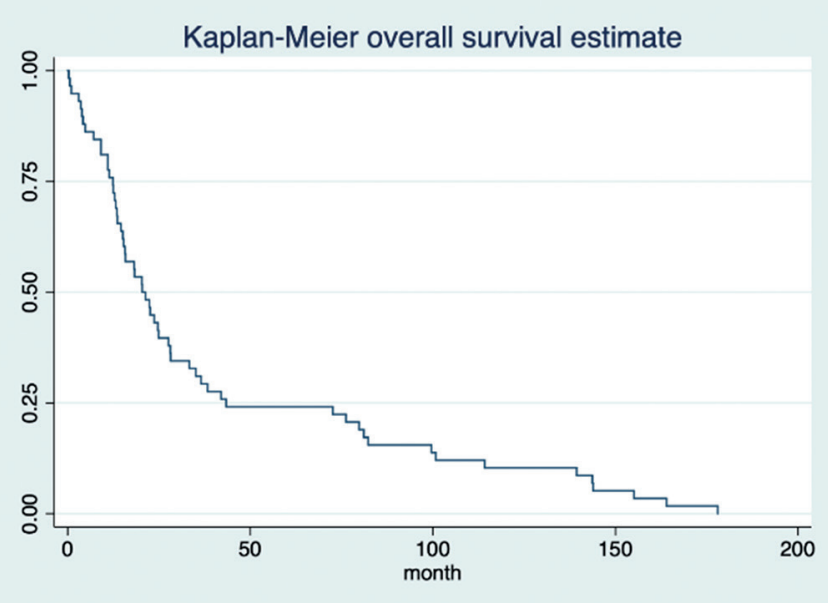

FIGURE 1 - Estimated overall survival of the cohort

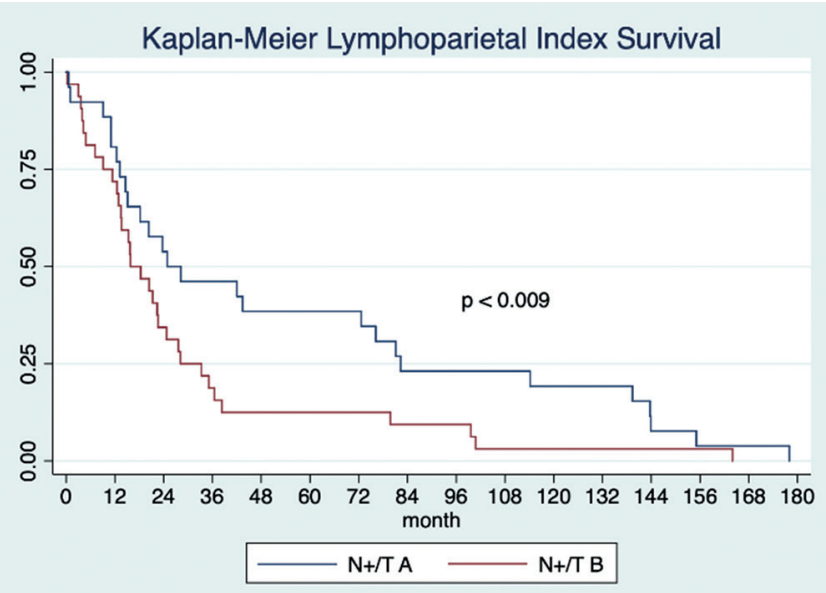

FIGURE 2 - Overall survival analysis according to lymphoparietal index subgroups $\mathrm{N}+/ \mathrm{TA}(0-0.5)$ and $\mathrm{N}+/ \mathrm{TB}(>0.5)$



FIGURE 3 - ROC curve analysis according to overall survival 
DISCUSSION

The main results of this study suggest the following: 1) the Chilean esophageal cancer is experimenting an epidemiological transition; 2) there are different variables that significantly predict the population susceptible to achieving postoperative long-term survival; 3 ) the lymphoparietal index is as accurate as TNM system for predicting survival more than three years in patients who underwent surgery for esophageal carcinoma with curative intent.

The esophageal cancer epidemiology has changed over the past 40 years. In our country, comparing previous reports to the present results: the location of the tumor in the lower esophagus has increased from $26 \%$ to $65 \%$, the adenocarcinoma increased from $14 \%$ to $52 \%$, and the surgical mortality dropped from $6 \%$ to $3 \% 3,7,29$. This changes probably are associated to the increase of Barrett's esophagus in de GERD secondary to overweight that in the last national surveillance program reaches $70 \%{ }^{11}$.

The SVg3 of the patients in this study was $32.7 \%$, which is very similar to previous national reports ${ }^{4,7,29}$, but lower than other international ones ${ }^{25,27,28}$. Some explanations for this numbers are: a) long period of study with worst results in the first years; b) high incidence of advanced disease in our cohort; and c) small sample size due to the low incidence of this pathology in our country that bias the impact of new advances in neoadjuvant and adjuvant therapy.

The prognostic effectiveness of the TNM classification to guide therapeutics is well known ${ }^{18}$. Recently, different complementary prediction factors of long-term survival have been described.

\section{Gender}

The results of this publication suggest an independent association between females and long-term survival with $p=0.03$ (OR: 3.9). This finding has been study by other groups, suggesting a possible estrogen protective effect, especially in adenocarcinoma ${ }^{17}$ but also squamous cell carcinoma ${ }^{21}$.

\section{Age}

The role of age in the prognosis of patients subjected to oncologic procedures has been studied many foregut cancers, being gastric ${ }^{8,12}$ and esophageal cancer ${ }^{20,24}$. These reports have demonstrated that older patients have an increased risk of surgical morbidity and lower long-term survival. These findings are not seen in the present study, which has been documented in other series as well ${ }^{27}$.

\section{Nutritional state}

The nutritional state has been studied by different authors in the preoperative and postoperative stages.

In a retrospective Brazilian study, Marin ${ }^{16}$ showed that lower BMI, lymphocytes and albumin, where associated with greater risk of infectious surgical complications and mortality, although no multivariable analysis was performed.

In a recent retrospective Japan study, Schichinohe ${ }^{22}$ demonstrated that not only $\mathrm{BMI}$ and cross-sectional area of the psoas muscle index, but also an index between these two variables were independent factors associated with higher risk of anastomosis leaks and 3-years overall survival.

In our study there was no independent correlation between BMI, weight loss, neither albumin level to OS3, which has been concluded by other as well ${ }^{14}$.

\section{Circulating tumor cells}

Measurement of circulating tumor cells (CTC) and its prognosis, has been study in different solid tumors including esophageal cancer ${ }^{19}$. Recently, a Chinese prospective study analyzed the levels of CTC in squamous cell esophageal carcinoma measured pre and post-surgery. The results showed that a change in CTC between first diagnosis and 13 days after surgery of $>2 / 7.5 \mathrm{ml}$ peripheral blood, is associated with lower progression-free-survival ${ }^{35}$.

\section{Localization, tumor grade and TNM}

Classically, tumor localization and grade of differentiation are associated with lower long-term survival. The previous actualization of AJCC guideline for esophageal cancer, allowed to differentiate between different subtypes according to localization and tumor grade ${ }^{18}$.

Interestingly, in a retrospective Chinese analysis of 302 esophageal carcinoma staged T3N0M0, Situ et al ${ }^{24}$, concluded that localization and tumor grade didn't have an independent influence on patient survival, this is supported by other study ${ }^{10,15}$. However, in a different analysis, with the same objective but in T2N0M0 patients, tumor grade shows to be an independent factor, whereas localization wasn't ${ }^{23}$.

Other publications have compared $6^{\text {th }}$ vs. $7^{\text {th }}$ TNM staging, concluding that $7^{\text {th }}$ edition is more accurate than $6^{\text {th }}$ in terms of prognosis ${ }^{15}$.

In our cohort neither the localization nor tumor grade affected long-term survival, while TNM staging was independent prognostic factors.

\section{Route of pull up and anastomotic fistula}

The anterior (AP) or posterior mediastinal pull-up (PP) dilemma, has been analyzed in different series, there has been even combinations of this techniques from posterior to anterior mediastinum after esophagectomy ${ }^{34}$.

Classically AP have had more leakages, lower ClavienDindo morbidity, and safer results if post-operative radiotherapy is required ${ }^{2,9}$

Recent evidence with minimally invasive surgery supports no difference in lymph node harvested, ICU and hospital stay, postoperative morbidity, and in-hospital mortality ${ }^{33}$.

A previous experience of our group showed similar rate of leaks for AP and PP ( $p>0,05)$, but a worst post-operative morbidity concentrating all types CD III-V and lower OS3 for $\mathrm{PP}^{5}$. In the present study we found that $\mathrm{AP}$ is an independent prognostic factor for long term survival, probably because the lower rate of severe post-operative morbidity.

\section{Adjuvant therapy}

Since CROSS study ${ }^{28}$, neoadjuvant chemo-radiation therapy is well stablished as a treatment standard in locally advance tumors with significant benefits. In our study we couldn't include adjuvant therapy in the analysis, this is due the absence of registration in more than $20 \%$ of patients, the information bias of this under-registration, cannot make conclusion reliable in adjuvant therapy. This happens because some health provisional system in our country, can mandate an externalization of the service to another institution.

\section{Lymphoparietal index}

Regarding the $\mathrm{N}+/ \mathrm{T}$ index, it has been validated in gastric cancer by our group ${ }^{13}$. The hypothesis is that lymph node metastatic potential of a tumor considering T classification could reliably predict patient prognosis and even be more accurate than TNM staging). In this study we found: a) lymphoparietal index is an independent prognostic factor $(p=0.02$, OR 3.9; Cl 95\% 1.01-15.17, Table 2); b) long-term survival probability is significant discriminated in both groups $\left(\mathrm{N}+/ \mathrm{T}_{A} \mathrm{vs} . \mathrm{N}+/ \mathrm{T}_{B^{i}}\right.$; $p=0.009$, Figure 1$) ; c)$ lymphoparietal index is comparable to TNM staging and even has better performance in OS3 prognosis ( $p=0.01$, Figure 2$)$.

The strengths of this investigation are the following: a) the analysis of the greatest number of prognostic variables for longterm survival for esophageal cancer reported in the domestic literature, and b) the provision of a new survival prediction 
index. The weaknesses are as follows: a) it covers a period of time in which there was a change in TNM classification, and treatment strategies, and b) it couldn't include the adjuvant therapy used in the analysis.

\section{CONCLUSION}

The independent prognostic factors for more than threeyears survival in treatment of esophageal cancer in a Latin American country are: gender, anterior mediastinal pull-up, anastomotic fistula, N classification, TNM stage, and lymphoparietal index. Concomitantly, it has been able to provide a new prognostic quotient in the evaluation of esophageal carcinoma patients who have been resected with curative intent, the lymphoparietal index.

\section{REFERENCES}

1. Braghetto I, Cardemil G, Lanzarini E, Musleh M,Mandiola C. Impact of minimally invasive surgery in the treatment of esophageal cancer. Arq Bras Cir Dig.2014;27:237-42.

2. Braghetto I, Cardemil G, Csendes A, Lanzarini E, Mushle M, Venturelli F, Mandiola C, Masia G, Gattini F. Resultados de la cirugía actual para e tratamiento del cáncer de esófago. Rev Chil Cir 2016:68:94-106

3. Braghetto I, Csendes A, Amat J, Cardemil G, Burdiles P, Blacud R, et al. Resección esofágica por cáncer: resultados actuales. Rev chil Cir 1996:48:214-224

4. Braghettol, Csendes A, Cardemil G, BurdilesP, KornO, Valladares H.Open transthoracic or transhiatal esophagectomy versus minimally invasive esophagectomy in terms of morbidity, mortality and survival. Surg Endosc. 2006;20:1681-6.

5. Braghettol,Figueroa-GiraltM,SanhuezaB, Valladares H,CardemilG,Cortés $\mathrm{S}$, Contreras C.Evoluciónypronósticooncológicodefístulasanastomóticas esofágicas en el tratamiento del cáncer de esófago. Estudio comparativo según vía de ascenso de tubo gástrico. Rev Chil Cir 2018:70:19-26

6. Butte JM, Becker F, Visscher A, Waugh E, Meneses M, Court I, et al. Cáncer de la unión gastroesofágica. Evaluación de los resultados quirúrgicos, sobrevida alejada y factores pronósticos en enfermos con terapia resectiva. Rev Med Chile 2010;138:53-60.

7. Csendes A, Velasco N, Medina E. Sobrevida de pacientes con carcinoma del esófago. Rev Med Chile 1979:107:610

8. Csendes A, Zamorano M, Figueroa M, Cortes S, Maluenda F, Musleh M, et al. Resultados del tratamiento quirúrgico en pacientes con cáncer gástrico de 80 o más años. Rev Chil Cir 2017;69:320-24

9. ChanML,HsiehCC,WangCW,Huang MH,HsuWH,HsuHS. Reconstruction after esophagectomy for esophageal cancer: Retrosternal or posterior mediastinal route? J Chin Med Assoc. 2011;74:505-10

10. Chen SB, Weng HR, Wang G, Yang JS, Yang WP, Liu DT, Chen YP, Zhang H. Prognosticfactorsand outcomeforpatientswithesophagealsquamouscell carcinoma underwent surgical resection alone: evaluation of the seventh edition of the American Joint Committee on Cancer staging system for esophageal squamous cell carcinoma. J Thorac Oncol. 2013;8:495-501

11. Departamento deEpidemiología. Ministerios de Salud deChile. Encuesta Nacional de Salud 2016-2017. 2018. [Online: https://www.minsal.cl/wpcontent/uploads/2018/01/2-Resultados-ENS_MINSAL_31_01_2018.pdf]

12. Figueroa-Giralt M. Factores pronósticos de sobrevida alejada en cáncer gástrico.IntroduccióndelnuevoínidceN+/T. Revchilcir2018:70:147-159.

13. Figueroa-Giralt M, Csendes A, Carrillo K, Danilla S, Lanzarini E, Braghetto I, Musleh M, Cortés S. Introduction of the new lymphoparietal index for gastric cancer patients. Arq Bras Cir Dig. 2019;32:e1441.

14. Hasegawa T, Kubo N, Ohira M, Sakurai K, Toyokawa T, Yamashita Y, et al. Impact of body mass index on surgical outcomes after esophagectomy for patients with esophageal squamous cell carcinoma. J Gastrointest Surg. 2015;19:226-33
15. Hsu PK, Wu YC, Chou TY, Huang CS, Hsu WH. Comparison of the 6th and 7th editions of the American Joint Committee on Cancer tumornode-metastasis staging system in patients with resected esophageal carcinoma. Ann Thorac Surg. 2010;89:1024-31

16. Marin F, Lamônica-Garcia V, Henry M, Burini R4. Grade of Esophageal Cancer And Nutritional Status Impact On Postsurgery Outcomes. Arq Gastroenterol. 2010;47:348-53

17. Mathieu LN, Kanarek NF, Tsai HL, Rudin CM, Brock MV. Age and sex differences in the incidence of esophageal adenocarcinoma: results from the Surveillance, Epidemiology, and End Results (SEER) Registry (1973-2008). Dis Esophagus. 2014;27:757-763.

18. NCCN Guidelines Version 1.2017, Esophageal Cancer.

19. Reeh M, Effenberger KE, Koenig AM, RiethdorfS, EichstädtD, VettorazziE, Uzunoglu FG, Vashist YK, Izbicki JR, Pantel Kand Bockhorn M: Circulating tumorcellsasabiomarkerforpreoperative prognosticstaging in patients with esophageal cancer. Ann Surg 2015;261:1124-1130.

20. Ruol A, Portale G, Castoro C, Merigliano S, Cagol M, Cavallin F. Effects of neoadjuvant therapy on perioperative morbidity in elderly patients undergoing esophagectomy for esophageal cancer. Ann Surg Oncol. 2007; $14: 3243-50$

21. Sanford NN, Mahal BA, Royce TJ, Pike LRG, Hwang WL. Sex Disparity and Copy Number Alterations in Esophageal Squamous Cell Carcinoma. Clin Gastroenterol Hepatol. 2019;17:1207-1209

22. Shichinohe T, Uemura S, Hirano S, Hosokawa M. Impact of Preoperative Skeletal Muscle Mass and Nutritional Status on Short-and Long-Term Outcomes AfterEsophagectomy forEsophageal Cancer:ARetrospective Observational Study : Impact of Psoas Muscle Mass and Body Mass on Esophagectomy. Ann Surg Oncol. 2019;26:1301-1310

23. Situ D, Wang J, Lin $P$, Long H, Zhang L, Rong T, Ma G. Do tumor location and grade affect survival in pT2N0M0 esophageal squamous cell carcinoma? J Thorac Cardiovasc Surg. 2013;146:45-51

24. Situ $D$, Wei $W$, Lin $P$, Long $H$, Zhang $L$, Fu J, Rong $T$, Ma G. Do tumor gradeand location affectsurvivalinesophageal squamouscell carcinoma? Survival analysis of 302 cases of pT3NOMO esophageal squamous cell carcinoma. Ann Surg Oncol. 2013 Feb;20:580-5

25. Tiesi G, Park W, Gunder M, Rubio G, Berger M, Ardalan B, Livingstone A, Franceschi D. Long-term survival based on pathologic response to neoadjuvanttherapyinesophageal cancer.JSurg Res.2017Aug;216:65-72

26. Toneto MG, Viola L. Current status of the multidisciplinary treatment of gastric adenocarcinoma. Arq Bras Cir Dig. 2018;31(2):e1373. doi: 10.1590/0102-672020180001e1373. Epub 2018 Jul 2. PMID: 29972401; PMCID: PMC6044205.

27. Tustumi, F., Kimura, C. M., Takeda, F. R., Uema, R. H., Salum, R. A., RibeiroJunior, U., \& Cecconello, I. Prognostic factors and survival analysis in esophageal carcinoma: ABCD. 2016; 29:138-141.

28. vanHagen $P$, HulshofM, vanLanschotJ,Steyerberg $E$, vanBergeHenegouwen M, Wijnhoven B, Richel D, et al. Preoperative Chemoradiotherapy for Esophageal or Junctional Cancer. N Engl J Med 2012; 366:2074-2084

29. VenturelliA:Cirugíamásradioterapia preypostoperatoriaenel tratamiento del cáncer esofágico intratorácico. Rev Chil Cir 1993; 45: 36-41

30. Venturelli A, Sánchez A, Cardemil B et al: Cáncer de esófago. Sobrevida a diez años plazo. Rev Chil Cir 2001; 53: 241-5

31. Venturelli A, Soto S, Díaz J, Cardemil B, Sánchez A, Jiménez L. Cáncer de esófago, tratamiento en el Hospital Clínico Regional de Valdivia durante el período 1982-2001. Rev. Chil Cir. 2003;55: 381-4

32. Venturelli F, Venturelli A, Cárcamo M, Cárcamo C. Terapia neoadyuvante en cáncer de esófago. Cuad. Cir. 2007; 21: 52-58

33. Yang J,XuC, LianD, YeS, ZengZ, LiuD,ZhuangC. Esophageal reconstruction: posterior mediastinal or retrosternal route. J Surg Res. 2016 201:364-9.

34. Yasuda T, Shiraishi O, Iwama M, Makino T, Kato $H$, Kimura Y. Novel esophageal reconstruction technique via transmediastinal route from posterior to anterior mediastinum after esophagectomy. J Thorac Cardiovasc Surg. 2018 Aug;156:859-66.

35. Zhang Y, Li J, Wang L, Meng P, Zhao J, Han P, et al. Clinical significance of detecting circulating tumor cells in patients with esophageal squamous cell carcinoma by EpCAM-independent enrichment and immunostaining-fluorescence in situ hybridization. Mol Med Rep. 2019;20:1551-1560 